\title{
Protective Effects of Sodium Selenite and Vitamin E on Mercuric Chloride-Induced Cardiotoxicity in Male Rats
}

\author{
Hatice Karaboduk $^{1}$, Meltem Uzunhisarcikli ${ }^{2 *}$ and Yusuf Kalender ${ }^{3}$ \\ ${ }^{1}$ Gazi University; Life Sciences Application and Research Center; Ankara - Turkey. ${ }^{2}$ Gazi University; Vocational \\ High School of Health Services; Ankara - Turkey. ${ }^{3}$ Gazi University; Faculty of Science, Department of Biology; \\ Ankara - Turkey
}

\begin{abstract}
This study was designed to investigate the protective effects of sodium selenite and/or vitamin E against mercuric chloride-induced cardiotoxicity. Male Wistar rats $(n=48,310 \pm 10$ g) were administered mercuric chloride (1.0 $\mathrm{mg} / \mathrm{kg} \mathrm{bw})$, sodium selenite $(0.25 \mathrm{mg} / \mathrm{kg} \mathrm{bw})$, vitamin $E(100 \mathrm{mg} / \mathrm{kg} \mathrm{bw})$, sodium selenite plus mercuric chloride, vitamin E plus mercuric chloride and sodium selenite plus vitamin E plus mercuric chloride daily via gavage for four weeks. Malondialdehyde (MDA) level, antioxidant enzyme activities [total superoxide dismutase (SOD), catalase (CAT), total glutathione peroxidase (GPx) and total glutathione-S-transferase (GST)], and histopathological changes in the heart tissue were evaluated. Results showed that mercuric chloride exposure resulted in an increase in the MDA level and a decrease in the SOD, CAT, GPX and GST activities, with respect to the control. Light microscopic investigations revealed that mercuric chloride induced histopathological changes in the heart tissue. A significant decrease in the MDA level and a significant increase in the SOD, CAT, GPx and GST activities were observed on the supplementation of sodium selenite and/or vitamin E to mercuric chloride-treated rats, which showed that, sodium selenite and/or vitamin E significantly reduced mercuric chloride induced cardiotoxicity, but not protected completely.
\end{abstract}

Key words: Mercuric chloride, Sodium selenite, Vitamin E, Cardiotoxicity, Oxidative Stress

\section{INTRODUCTION}

Heavy metals are highly persistent and can bioaccumulate and biomagnify in the food chain, thus becoming toxic to living organisms (Deepmala et al. 2013). Mercury, a well-known toxicant, is a heavy metal that comes from natural as well as artificial sources (Zhang et al. 2013). Mercury can be found in three basic forms (elemental, inorganic mercury and organic mercury) with various toxicological profiles (Oliveria et al. 2012). Inorganic mercury compounds are known to induce toxicity in a number of different biological systems, including the reproductive system (Kalender et al. 2013), central nervous system and urinary system (Patrick 2002). Souza de Assis et al. (2003) reported that inorganic mercury was capable of producing profound cardiotoxicity.

The general toxic effect of heavy metals is considered to be a result of the inactivation of enzymes and/or functional proteins by directly binding to them (Tsuji et al. 2002). This may be partly due to oxidative damage by formation of reactive oxygen species (ROS) (Stohs and Bagchi 1995). Oxidative stress developing with the production of ROS can lead to the development of many pathological changes (Morakinyo et al. 2012). For example, mercury has been attributed to the formation of ROS (Bharathi et al. 2012).

*Author for correspondence: babatuhan@gmail.com 
Antioxidant enzymes such as SOD, CAT and GPx protect cellular homeostasis from oxidative damage by ROS generated through the reduction of molecular oxygen (Sanz et al. 2002).

Antioxidants are known to reduce ROS-induced damage (El-Demerdash 2004). Selenium is an essential trace element for animals and humans, which protects the cells against oxidative damage by the expression of selenoprotein genes and through anti-inflammatory mechanisms (Said et al. 2014). It is an integral component of the cytosolic enzyme GPx and facilitates the action of vitamin $\mathrm{E}$ in reducing peroxy radicals (Kaneko 1989). Selenium has detoxification effect on various heavy metals (Diplock et al. 1986). Vitamin E ( $\alpha$ tocopherol) is a naturally occurring, potent lipidsoluble, chain-breaking antioxidant. It protects cellular membranes and lipoprotein surfaces from lipid peroxidation (Al-Othman et al. 2011). Its protective role has been reported against the heavy metal toxicity in experimental animals (Agarwal et al. 2010). Synergistic effect of antioxidants such as selenium and vitamin $\mathrm{E}$ is the most powerful in reducing storage and toxicity of ROS (Schwenke et al. 1998; Aslam et al. 2010).

Antioxidant supplementation has been beneficial in metal toxicity. The aims of the present study were: (i) to evaluate the effect of mercuric chloride on lipid peroxidation and antioxidant enzyme activities, such as SOD, CAT, GPx and GST of heart tissues, (ii) to examine of histopathological changes in the heart tissues, and (iii) to investigate the possible protective role of sodium selenite and/or vitamin $\mathrm{E}$ against mercuric chloride.

\section{MATERIALS AND METHODS}

\section{Chemicals}

Mercuric chloride $\left(\mathrm{HgCl}_{2} ; 99 \%\right.$ purity) and sodium selenite $\left(\mathrm{Na}_{2} \mathrm{SeO}_{3} ; 99 \%\right.$ purity) were obtained from Sigma Aldrich (Germany). Vitamin E (DL- $\alpha$-tocopherol acetate; $500 \mathrm{mg}$ DL- $\alpha$ tocopherol acetate per ml) was supplied by Merck (Germany).

\section{Animals}

Healthy male Wistar rats of weighing between $310 \pm 10 \mathrm{~g}$ were used for this study. Rats were obtained from the Gazi University Laboratory Animals Growing and Experimental Research
Center. Animals were housed in plastic cages, with six animals per cage and allowed to acclimatize to the laboratory environment for 10 days. Animals were maintained under controlled conditions at $22 \pm 3^{\circ} \mathrm{C}$ and $12: 12 \mathrm{~h}$ light-dark cycle. The animals were fed with standard rat pellet food and water ad libitum. The experimental protocols were approved by the Gazi University Committee on the Ethics of Animal Experimentation (Approval number: G.U. ET-10.026).

\section{Experimental Procedure}

Rats were treated orally with the tested compounds for four weeks. They were randomly divided into eight groups, each consisting of six rats. Group 1, labeled as control group, was treated with $1.0 \mathrm{ml} / \mathrm{kg}$ bw corn oil per day; Group 2 was treated with sodium selenite $(0.25 \mathrm{mg} / \mathrm{kg}$ bw per day in distilled water) (Koyuturk et al. 2007); Group 3 was treated with vitamin E (100 $\mathrm{mg} / \mathrm{kg}$ bw per day in corn oil) (El-Demerdash et al. 2004); Group 4 was treated with sodium selenite plus vitamin $\mathrm{E}(0.25 \mathrm{mg} / \mathrm{kg}$ bw +100 $\mathrm{mg} / \mathrm{kg}$ bw per day); Group 5 was treated with mercuric chloride $(1.0 \mathrm{mg} / \mathrm{kg}$ bw per day in distilled water) (Ramalingam et al. 2002); Group 6 was treated with sodium selenite plus mercuric chloride $(0.25 \mathrm{mg} / \mathrm{kg} \mathrm{bw}+1.0 \mathrm{mg} / \mathrm{kg}$ bw per day); Group 7 was treated with vitamin E plus mercuric chloride $(100 \mathrm{mg} / \mathrm{kg} \mathrm{bw}+1.0 \mathrm{mg} / \mathrm{kg}$ bw per day); Group 8 was treated with sodium selenite plus vitamin $\mathrm{E}$ plus mercuric chloride $(0.25$ $\mathrm{mg} / \mathrm{kg}+100 \mathrm{mg} / \mathrm{kg}$ bw+1.0 mg/kg bw per day). None of the rats died during the experimental period.

The substances were administrated in the morning (between 09:00 and 10:00 h) to non-fasted rats. The first day of exposure to test compounds was considered as experimental day 0 . At the end of the $4^{\text {th }}$ week (28 days) of treatment, all the animals were sacrificed and dissected. The heart tissues were quickly excised to light microscope investigations and biochemical examinations.

\section{Biochemical Estimation Tissue Homogenate Preparation}

The heart tissues were dissected and washed with sodium phosphate buffer at $\mathrm{pH}$ 7.2. Tissue samples were stored at $-80^{\circ} \mathrm{C}$ until the analysis. The tissues were homogenized with a Teflon homogenizer (Heidolph Silent Crusher M). The 
homogenates were centrifuged. Antioxidant enzyme activities and MDA level were specified by measuring the absorbance of the samples with spectrophotometer (Shimadzu UV 1700, Kyoto, Japan). Protein content of the supernatant was determined according to the method of Lowry et al. (1951) using bovine serum albumin (BSA) as standard.

\section{Lipid Peroxidation Assay}

MDA level was determined using the thiobarbituric acid (TBA) test described by Ohkawa et al. (1979). The heart tissues were incubated at $95^{\circ} \mathrm{C}$ with TBA under aerobic conditions ( $\mathrm{pH}$ 3.4) and absorbance was measured at $532 \mathrm{~nm}$ to assay the MDA level. The results were expressed as nmol MDA formed per milligram of protein.

\section{Antioxidant Enzyme Activities Assays}

Total SOD activity was measured according to the method of Marklund and Marklund (1974) by analysing the autooxidation and illumination of pyrogallol at $440 \mathrm{~nm}$ for $3 \mathrm{~min}$. One unit of total SOD activity was calculated as the amount of protein that caused 50\% pyrogallol autooxidation inhibition. The total SOD activity was expressed as $\mathrm{U} / \mathrm{mg}$ protein. A blank without homogenate was used as a control for non-enzymatic oxidation of pyrogalol in Tris-EDTA buffer $(50 \mathrm{mM}$ Tris, 10 mM EDTA, $\mathrm{pH}$ 8.2).

CAT activity was determined according to the method of Aebi (1984), based on the hydrolysis of hydrogen peroxide $\left(\mathrm{H}_{2} \mathrm{O}_{2}\right)$ and the resulting decrease in the absorbance at $240 \mathrm{~nm}$ over a $3 \mathrm{~min}$ period at $25^{\circ} \mathrm{C}$. Before determination of the CAT activity, the samples were diluted 1:9 with $1 \%$ (v/v) Triton X-100. CAT activity was expressed as milimoles of $\mathrm{H}_{2} \mathrm{O}_{2}$ reduced per minute per milligram of protein using an extinction coefficient of $0.0394 \mathrm{mM}^{-1} \mathrm{~cm}^{-1}$. A blank without homogenate was used as a control for nonenzymatic hydrolysis of peroxide in phosphate buffer (50 mM, pH 7.0).

Total GPx activity was determined according to the method of Paglia and Valentine (1967), using $\mathrm{H}_{2} \mathrm{O}_{2}$ as substrate. The reaction was monitored indirectly as the oxidation rate of NADPH at 240 $\mathrm{nm}$ for $3 \mathrm{~min}$. Enzyme activity was expressed as micromoles of NADPH consumed per minute per milligram of protein, using an extinction coefficient of $6.220 \mathrm{M}^{-1} \mathrm{~cm}^{-1}$. A blank without homogenate was used as a control for non- enzymatic oxidation of NADPH upon addition of hydrogen peroxide in $0.1 \mathrm{M}$ Tris buffer, $\mathrm{pH}$ 8.0. Total GST activity was assayed by measuring the formation of GSH (Glutathione) and the 1-chloro2, 4-dinitrobenzene (CDNB) conjugate (Habig et al. 1974). The increase in absorbance was recorded at $340 \mathrm{~nm}$ for $3 \mathrm{~min}$. The specific activity of GST is expressed as nanomoles GSHCDNB conjugate formed $/ \mathrm{min} / \mathrm{mg}$ protein using an extinction coefficient of $9.6 \mathrm{mM}^{-1} \mathrm{~cm}^{-1}$. All assays were corrected for non-enzymatic conjugation using a corresponding substrate $25 \mathrm{mM}$ CDNB and $20 \mathrm{mM} \mathrm{GSH}$ in in $50 \mathrm{mM}$ phosphate buffer, pH 7.0.

\section{Histopathology}

For histopathological examination, parts of the cardiac tissue obtained from each animal were fixed in Bouin solution. Then the tissue samples were processed using a graded ethanol series, and embedded in paraffin. Paraffin sections were cut into 6-7 $\mu \mathrm{m}$-thick slices and stained with hematoxylin and eosin (H\&E) for histological examination. The sections were examined and photographed using an Olympus light microscope (Olympus BX51, Tokyo, Japan) with an attached digital photograph machine (Olympus E-330, Olympus Optical Co. Ltd., Japan).

\section{Statistical Analysis}

Data of the present study were evaluated by SPSS 11.0 for Windows. The significance of differences in the values of the control and treated animals was calculated using one-way analysis of variance (ANOVA), followed by Tukey's procedure for multiple comparisons. All values were expressed as means $\pm \mathrm{SD}$. A value of $\mathrm{P}<0.05$ was considered to be significant.

\section{RESULTS}

\section{Evaluation of Biochemical Parameters}

At the end of the study period, there were no statistically significant changes in MDA level (Fig. 1) and SOD, CAT, GPx and GST activities in the sodium selenite-, vitamin E- and sodium selenite plus vitamin E-treated groups compared to the control group (Table 1).

\section{MDA Level}

MDA is the most abundant individual aldehyde resulting from lipid peroxidation breakdown in 
biological systems and is commonly used as an indirect index of lipid peroxidation. When the mercuric chloride-, sodium selenite plus mercuric chloride-, vitamin E plus mercuric chloride- and sodium selenite plus vitamin E plus mercuric chloride-treated groups were compared with the control group at the end of $4^{\text {th }}$ week, a significantly increase in the MDA level in the heart tissues was observed. The MDA level decreased statistically significantly in the sodium selenite plus mercuric chloride-, vitamin E plus mercuric chloride- and sodium selenite plus vitamin $\mathrm{E}$ plus mercuric chloride- treated groups compared to mercuric chloride-terated group $(\mathrm{P}<0.05$, Fig. 1).

Table 1 - Effects of exposure to mercuric chloride on the antioxidant enzyme activities in heart tissue of male Wistar rats.

\begin{tabular}{|c|c|c|c|c|}
\hline Groups & $\begin{array}{c}\text { SOD } \\
\text { (U/mg protein) }\end{array}$ & $\begin{array}{c}\text { CAT } \\
(\mathrm{mM} / \mathrm{mg} \text { protein }) \\
\end{array}$ & $\begin{array}{c}\text { GPx } \\
(\mu \mathrm{M} / \mathbf{m g} \text { protein })\end{array}$ & $\begin{array}{c}\text { GST } \\
\text { (nM/mg protein) }\end{array}$ \\
\hline Control & $11.163 \pm 0.673$ & $4.227 \pm 0.251$ & $3.004 \pm 0.134$ & $0.039 \pm 0.002$ \\
\hline Sodium selenite & $10.051 \pm 0.853$ & $3.967 \pm 0.230$ & $2.965 \pm 0.145$ & $0.036 \pm 0.002$ \\
\hline Vitamin E & $10.170 \pm 0.733$ & $4.032 \pm 0.250$ & $2.895 \pm 0.136$ & $0.037 \pm 0.002$ \\
\hline Sodium Selenite+Vitamin E & $9.952 \pm 0.828$ & $3.809 \pm 0.303$ & $2.810 \pm 0.132$ & $0.036 \pm 0.002$ \\
\hline Mercuric chloride & $5.175 \pm 0.821^{\mathrm{a}, \mathrm{b}, \mathrm{c}, \mathrm{d}}$ & $1.183 \pm 0.319^{\mathrm{a}, \mathrm{b}, \mathrm{c}, \mathrm{d}}$ & $0.973 \pm 0.127^{\mathrm{a}, \mathrm{b}, \mathrm{c}, \mathrm{d}}$ & $0.014 \pm 0.002^{\mathrm{a}, \mathrm{b}, \mathrm{c}, \mathrm{d}}$ \\
\hline $\begin{array}{l}\text { Sodium selenite+Mercuric } \\
\text { chloride }\end{array}$ & $7.362 \pm 0.884^{\mathrm{a}, \mathrm{b}, \mathrm{c}, \mathrm{d}, \mathrm{e}}$ & $2.450 \pm 0.300^{\mathrm{a}, \mathrm{b}, \mathrm{c}, \mathrm{d}, \mathrm{e}}$ & $2.066 \pm 0.138^{\mathrm{a}, \mathrm{b}, \mathrm{c}, \mathrm{d}, \mathrm{e}}$ & $0.023 \pm 0.002^{\mathrm{a}, \mathrm{b}, \mathrm{c}, \mathrm{d}, \mathrm{e}}$ \\
\hline $\begin{array}{l}\text { Vitamin E+Mercuric } \\
\text { chloride }\end{array}$ & $7.458 \pm 0.802^{\mathrm{a}, \mathrm{b}, \mathrm{c}, \mathrm{d}, \mathrm{e}}$ & $2.466 \pm 0.257^{\mathrm{a}, \mathrm{b}, \mathrm{c}, \mathrm{d}, \mathrm{e}}$ & $2.103 \pm 0.121^{\mathrm{a}, \mathrm{b}, \mathrm{c}, \mathrm{d}, \mathrm{e}}$ & $0.021 \pm 0.002^{\mathrm{a}, \mathrm{b}, \mathrm{c}, \mathrm{d}, \mathrm{e}}$ \\
\hline $\begin{array}{l}\text { Sodium selenite +Vitamin } \\
\text { E+Mercuric chloride }\end{array}$ & $7.340 \pm 0.783^{a, b, c, d, e}$ & $2.422 \pm 0.246^{\mathrm{a}, \mathrm{b}, \mathrm{c}, \mathrm{d}, \mathrm{e}}$ & $2.075 \pm 0.146^{\mathrm{a}, \mathrm{b}, \mathrm{c}, \mathrm{d}, \mathrm{e}}$ & $0.023 \pm 0.003^{\mathrm{a}, \mathrm{b}, \mathrm{c}, \mathrm{d}, \mathrm{e}}$ \\
\hline
\end{tabular}

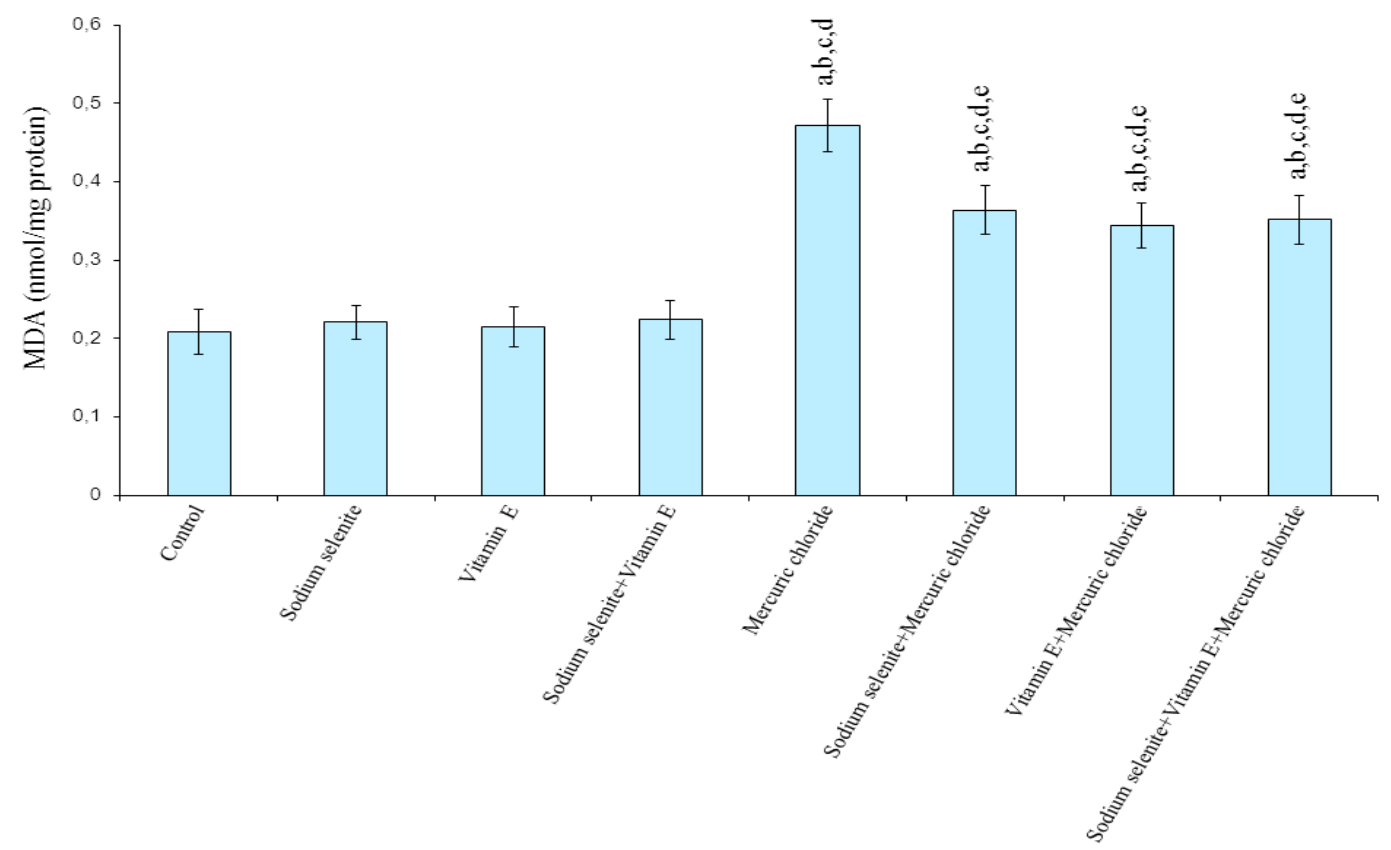

Figure 1 - Effects of subacute treatment of mercuric chloride on MDA level in the heart tissue of male Wistar rats. Each bar represents mean \pm Standard Deviation of six animals in each group. Significance at $\mathrm{P}<0.05$. ${ }^{\mathrm{a}}$ Comparison of control and other groups. ${ }^{\mathrm{b}}$ Comparison of sodium selenite-treated group and other groups. ${ }^{\mathrm{c} C}$ Comparison of vitamin E-treated group and other groups. ${ }^{\mathrm{d}}$ Comparison of sodium selenite plus vitamin E-treated group and other groups. ${ }^{\mathrm{e}}$ Comparison of mercuric chloride-treated group and other groups. 


\section{Antioxidant Enzyme Activities}

A significant decrease was observed in SOD, CAT, GPx and GST activities at the end of the $4^{\text {th }}$ week in mercuric chloride-, sodium selenite plus mercuric chloride-, vitamin E plus mercuric chloride- and sodium selenite plus vitamin E plus mercuric chloride-treated groups compared to the control group $(\mathrm{P}<0.05$, Table 1$)$. However, SOD, CAT, GPx and GST activities significantly increased in the sodium selenite plus mercuric chloride-, vitamin E plus mercuric chloride- and sodium selenite plus vitamin E plus mercuric chloride-treated groups compared to the mercuric chloride-treated group at the end of the $4^{\text {th }}$ week $(\mathrm{P}<0.05$, Table 1$)$.

\section{Histopathological Changes}

The results of the histopathological examination is shown in Figure 2. Light microscopy showed no cardiac injury in the control group (Fig. 2A) and antioxidant groups (sodium selenite-, vitamin Eand sodium selenite plus vitamin E-treated groups) at the end of the $4^{\text {th }}$ week.

Histopathological changes were observed in the heart tissue of the mercuric chloride-, sodium selenite plus mercuric chloride-, vitamin E plus mercuric chloride- and sodium selenite plus vitamin $\mathrm{E}$ plus mercuric chloride- treated groups. There were inflammatory cell infiltration, disorganization of myocardial fibers, edema in interstitial tissue of heart, degeneration of cardiac myocytes and necrosis (Figs. 2B-D).

Edema in interstitial tissue of heart, vacuolar degeneration and mild disorganization of myocardial fibers were observed in the sodium selenite plus mercuric chloride-, vitamin E plus mercuric chloride- and sodium selenite plus vitamin $\mathrm{E}$ plus mercuric chloride-treated groups (Figs. 2E-G).
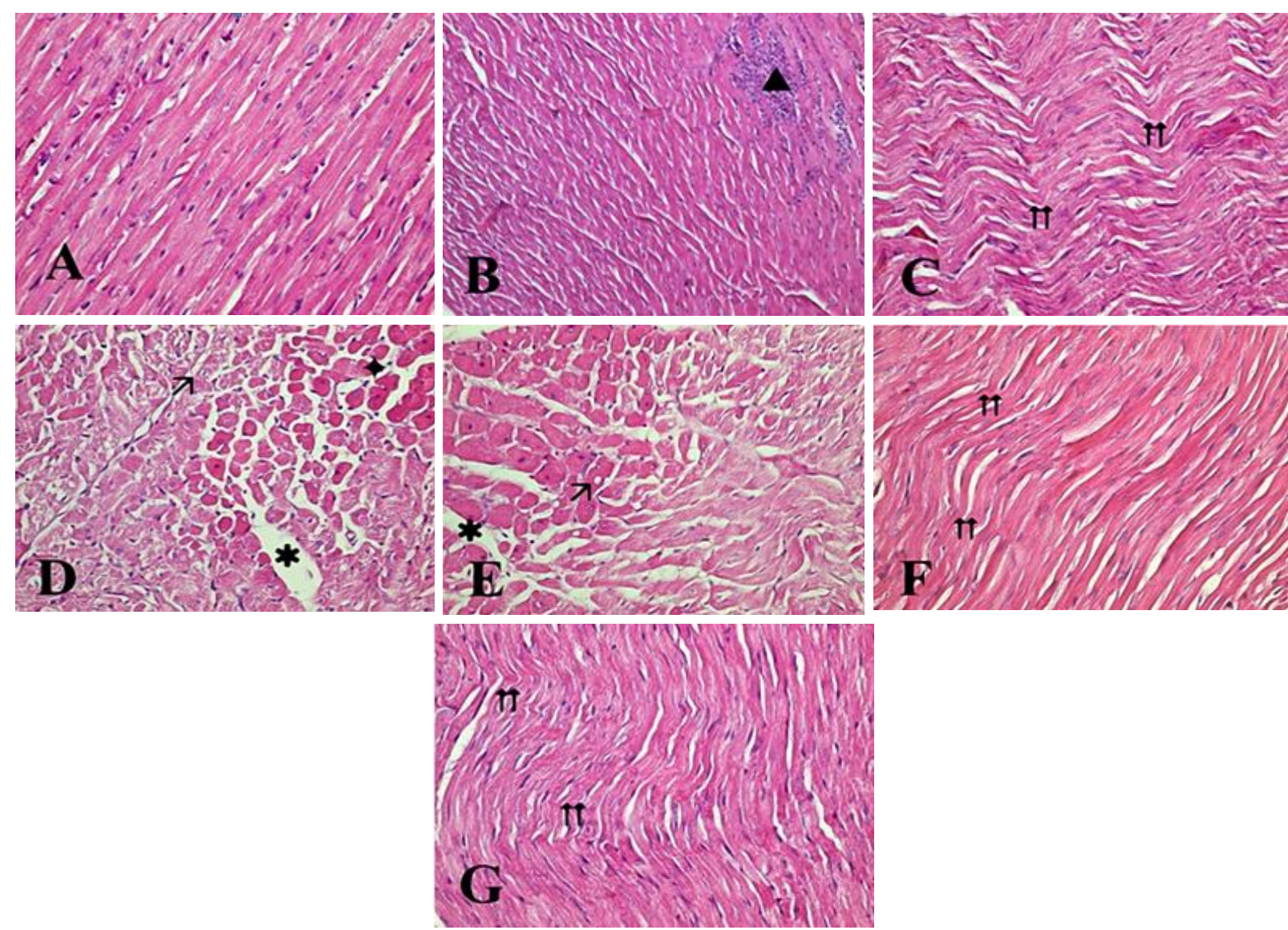

Figure 2- (A) Heart section of control rats, $\times 400$. (B-D) Heart sections of mercuric chloride-treated rats showing inflammatory cell infiltration $(\boldsymbol{A}), \times 200(B)$, disorganization $(\uparrow \uparrow)$ of myocardial fibers, $\times 400(C)$, degeneration $(\pi)$ of cardiac myocytes, edema $(*)$ in interstitial tissue of heart and necrosis $(\uparrow), \times 400$ (D). (E) Heart section of sodium selenite plus mercuric chloride-treated rats showing edema $(\boldsymbol{*})$ in interstitial tissue of heart and vacuolar degeneration $(\boldsymbol{\lambda})$ of cardiac muscle cells, $\times 400$. (F-G, respectively) Heart section of vitamin E plus mercuric chloride, sodium selenite plus vitamin E plus mercuric chloride-treated rats showing mild disorganization ( $\uparrow$ ) of myocardial fibers, $\times 400$. 


\section{DISCUSSION}

It is well known that heavy metals are commonly found in environment such as in the soil, plants and animals (Jayakumar et al. 2009). Some heavy metals can cause physiological, biochemical and histological alterations (Al-Attar 2011). Several risk factors, including the industrial pollution of the environment with metal compounds are associated with cardiovascular diseases (Soudani et al. 2011). Mercury is one of the most toxic metals. It promotes the generation of ROS such as superoxide and hydrogen peroxides, which induce oxidative stress, resulting in cell injury (Bharathi et al. 2012).

The cardiovascular effects of mercury toxicity have not been attentively evaluated until recently. Yoshizawa et al. (2002) reported that mercury exposure was associated with developing cardiovascular disease. Houston (2011) found that mercury toxicity was associated with cardiovascular disorders, including hypertension, coronary heart disease, myocardial infarction, cardiac arrhythmias, reduced heart rate variability and generalized atherosclerosis. Oxidative stress plays an important role in the pathogenesis and development of cardiovascular diseases (Prince et al. 2011).

Oxidative stress is defined as a serious imbalance between generation of free radical and antioxidant capacity (Halliwell 2011). It has been previously reported that mercuric chloride increased the formation of ROS, which could lead to lipid peroxidation and cause oxidative stress (Durak et al. 2010; Haibo et al. 2011). Lipid peroxidation, a free radical-generating system, has been suggested to be closely related with mercury-induced tissue damage (Tunali-Akbay et al. 2007). MDA is one of the major oxidation products of peroxidized polyunsaturated fatty acids (Durak et al. 2010) and increased MDA level is an important indicator of the degree of lipid peroxidation (Tunali-Akbay et al. 2007). In the present study, the elevated lipid peroxidation level was observed in the heart tissue of mercuric chloride-treated rats. Enhanced MDA level observed was in agreement with the study of Tunali-Akbay et al. (2007) who observed an increase in MDA level of rat heart after acute administration of mercuric chloride. The elevated level of MDA could be due to an increase in free radicals resulting from the induction of oxidative stress in the heart tissue. MDA level could be used as a indicator of tissue damage induced by mercuric chloride. Several studies have shown that intoxication with mercury causes increased lipid peroxidation level in various animal tissues (Su et al. 2008; Bharathi et al. 2012; Kalender et al. 2013).

Biological systems, under normal physiological conditions are protected from oxidative damage of the ROS by the antioxidative defense systems, including enzymatic and non-enzymatic scavengers (Priya et al. 2011). Free radical scavenging enzymes such as SOD, CAT, GPx and GST are the first line of cellular defense against the toxic effects of ROS (Priscilla and Price 2009) and they are widely used as biomarkers of oxidative stress (Uzun et al. 2010). The myocardium has antioxidative defense systems to neutralize free radicals. But, the heart has been reported to be more vulnerable to oxidative damage as it has less endogenous antioxidant enzyme activity compared to some tissues (Kumar and Gupta 2011). The mechanism by which mercury mediates cardiovascular toxicity is not fully elucidated (Azevedo et al. 2012). Several mechanisms have been proposed, including an increase in oxidative stress via production of free radicals and a reduction in the activity of antioxidant enzymes (Azevedo et al. 2012; Amara et al. 2014).

SOD and CAT mutually function as important enzymes in the elimination of ROS (Boujbiha et al. 2011). SOD catalyzes the conversion of superoxide radicals to hydrogen peroxide and molecular oxygen, while CAT catalyzes the breakdown of toxic $\mathrm{H}_{2} \mathrm{O}_{2}$ to water and oxygen (Boujbiha et al. 2011). Glutathione peroxidases are main enzymes in the antioxidant defence system of living organisms, and protect organisms against oxidative stress (Wang et al. 2014). All glutathione peroxidases reduce hydrogen peroxide and alkyl hydroperoxides at the expense of GSH (BrigeliusFlohé 1999). Glutathione S-transferases are major phase II detoxifying enzymes and play an important role in the detoxification and excretion of xenobiotics (Boyer et al. 1984). They catalyze the conjugation of a variety of electrophilic substrates to the thiol group of GSH, producing less toxic substances (Mansour and Mossa 2009). Mercuric chloride has been reported to significantly inhibit the antioxidant enzyme activities in various rat tissues (Kalender et al. 2013; Aslanturk et al. 2014). In this study, all assayed antioxidant enzyme activities significantly decreased in the heart tissue of mercuric chloride- 
treated rats. This decrease in the SOD, CAT, GPx and GST activities could be the result of increased in ROS production. Decreased SOD activity in the mercuric chlorid-treated rats could be due to an excessive formation of superoxide anions which would affect enzyme structure (Bharathi et al. 2012). The inhibition of CAT and GPx activities occurred probably as a defense response used against hydrogen peroxide generated by mercuric chloride (Bharathi et al. 2014). In addition, decreased GST activity may indicate insufficient detoxification of mercury in rat heart tissue (Mansour and Mossa 2009). The decrease in the antioxidant enzyme activities and increase in lipid peroxidation could explain the induction of free radicals in mercuric chloride-treated rats.

Antioxidants provide protection against injurious effect of free radical attack in the biological system (Al-Othman et al. 2011). Selenium and vitamin $\mathrm{E}$ are important components of the antioxidant defense system that helps to protect cell from oxidative damage (Aslanturk et al. 2014). Selenium is an essential dietary trace element, which is an integral part of many proteins with catalytic and structural functions (Hatfield et al. 2014). It also facilitates the action of vitamin $E$ in reducing peroxyl radicals through permitting higher levels of vitamin $\mathrm{E}$ to be absorbed (Machlin 1991). The interaction between mercury and selenium in the body of mammals has been well reported (Jureša et al. 2005). Selenium has been proposed to sequentially bind to mercury and selenoprotein $\mathrm{P}$ in the bloodstream, to form a nontoxic complex (Perottoni et al. 2004). Formation of mercury-selenium complex with selenoprotein $\mathrm{P}$ induces redistribution of mercury in the body or reduces the absorption of mercury (Su et al. 2008). In the present study, the protective effect sodium selenite against mercuric chloride-induced toxicity could be due to its antioxidant effects or to render a stable form and biologically inert complex with mercury. Vitamin E is a lipid-soluble vitamin that is present in cell membranes. Its main antioxidant function is to protect the cell membrane integrity against lipid peroxidation through its chainbreaking antioxidant activity (Brigelius-Flohé 2009). In the present study, vitamin $E$ showed protective effect against mercuric chloride. This effect could be due to impaired absorption of mercury in the gastrointestinal tract and/or its antioxidant effect (Kalender et al. 2013). Selenium and/or vitamin $\mathrm{E}$ protect various tissues against damages induced by heavy metals (Rana et al.
1996; Perottoni et al. 2004; Kalender et al. 2013). Recently, Kalender et al. (2013) showed that the supplementation of sodium selenite and/or vitamin $\mathrm{E}$ to mercury-treated rats declined lipid peroxidation, increased SOD, CAT and GPx activities along with milder histopathological lesions in testis tissues. Selenium and vitamin E have a synergetic effect (Aslam et al. 2010). Vitamin E prevents oxidative damage to sensitive membrane lipids by destroying hydroperoxide formation, acting in conjunction with selenium, and protects cellular membranes and lipid containing organelles from peroxidative damage by oxidative stress (Gupta et al. 2005). In the present study, supplementation of sodium selenite and/or vitamin $\mathrm{E}$ to mercuric chloride-treated rats increased SOD, CAT, GPx and GST activities and thereby improved the antioxidant/prooxidant balance of the heart tissue. The enhanced antioxidant capacity along with the decreased levels of MDA in antioxidant groups reflected the decreased oxidative damage in the heart tissue. The protective effects of sodium selenite and/or vitamin $\mathrm{E}$ could be related to the formation of a selenium-mercury complex and impaired absorption of mercury in the presence of vitamin $\mathrm{E}$ in the gastrointestinal tract and also their antioxidant effects.

Toxic metals can lead to histopathological changes in the myocardium (Soudani et al. 2011; Ansaria et al. 2013). In this study, mercuric chloride treatment caused histopathological changes such as inflammatory cell infiltration, edema, vacuolar degeneration, disorganization of myocardial fibers and necrosis in heart tissue. It is known that mercury produces ROS (Mahboob et al. 2001). The ROS attack the cell membrane and lead to destabilization and disintegration of cell membrane as a result of lipid peroxidation (Stajn et al. 1997). Histopatological changes in the heart tissue could be due to increased lipid peroxidation and ROS generation, which in turn, induces oxidative stress. The light microscopic findings support the result of the biochemical assays. Soudani et al. (2011) reported that chromium (VI) treatment caused histopathological changes such as myonecrosis, vacuolization, hemorrhage and fibrosis in the cardiac tissues of rats. In this study, the necrosis observed in the heart tissue of the mercuric chloride-treated rats did not exist in the rats that received sodium selenite and/or vitamin $\mathrm{E}$ co-administration. Moreover, inflammatory cell infiltration, disorganization of myocardial fibers 
and edema were observed in the mercuric chloride-treated groups; these changes were less severe in the sodium selenite and/or vitamin E plus mercuric chloride-treated groups. Thus, vitamin $\mathrm{E}$ and/or sodium selenite could ameliorate the heart tissue damage induced by mercuric chloride exposure.

\section{CONCLUSIONS}

The the present study showed that mercuric chloride intoxication induced oxidative stress in heart tissue of rats through the generation of free radicals and alteration of the cellular antioxidant defense system. The supplementation of sodium selenite and/or vitamin $\mathrm{E}$ proved beneficial in reducing the toxic effects of mercuric chloride induced in the heart tissue.

\section{ACKNOWLEDGMENTS}

The authors are thankful to the Gazi University Research Fund for support.

\section{REFERENCES}

Aebi H. Catalase in vitro. Method Enzymol. 1984; 105: 121-126.

Agarwal R, Goel SK, Chandra R, Behari JR. Role of vitamin $\mathrm{E}$ in preventing acute mercury toxicity in rat. Environ Toxicol Phar. 2010; 29: 70-78.

Al-Attar AM. Antioxidant effect of vitamin E treatment on some heavy metals-induced renal and testicular injuries in male mice. Saudi J Biol Sci. 2011; 18: 6372.

Al-Othman AM, Al-Numair KS, El-Desoky GE, Yusuf K, Al Othman ZA, Aboul-Soud MAM, et al. Protection of $\alpha$-tocopherol and selenium against acute effects of malathion on liver and kidney of rats. African J Pharm Pharmacol. 2011; 5: 1054-1062.

Amara IEA, Elshenawya OH, Abdelradya M, El-Kadia AOS. Acute mercury toxicity modulates cytochrome P450, soluble epoxide hydrolase and their associated arachidonic acid metabolites in $\mathrm{C} 57 \mathrm{~B} 1 / 6$ mouse heart. Toxicol Lett. 2014; 226: 53-62.

Ansaria MA, Maayaha ZH, Bakheeta SA, El-Kadib AO, Korashya HM. The role of aryl hydrocarbon receptor signaling pathway in cardiotoxicity of acute lead intoxication in vivo and in vitro rat model. Toxicology. 2013; 306: 40-49.
Aslam F, Khan A, Khan MZ, Sharaf S, Gul ST, Saleemi MK. Toxico-pathological changes induced by cypermethrin in broiler chicks: Their attenuation with Vitamin E and selenium. Exp Toxicol Pathol. 2010; 62: 441-450.

Aslanturk A, Uzunhisarcikli M, Kalender S, Demir F. Sodium selenite and vitamin $\mathrm{E}$ in preventing mercuric chloride induced renal toxicity in rats. Food Chem Toxicol. 2014; 70: 185-190.

Azevedo BF, Furieri LB, Pecanha FM, Wiggers GA, Vassallo PF, Simoes MR, et al. Toxic effects of mercury on the cardiovascular and central nervous systems. J Biomed Biotechnol. 2012; 1-11.

Bharathi E, Jagadeesan G, Manivasagam T. Influence of s-allyl cysteine against mercuric chloride induced nephrotoxicity in albino rats. J Chem Pharm Res. 2012; 4: 1470-1474.

Bharathi E, Jagadeesan G, Vijayakumar M. Hepatoameliorative effect of hesperidin and ellagic on mercuric chloride intoxicated rats. Biomed Agi Pathol. 2014; 4: 17-21.

Boujbiha MAM, Hamden K, Guermazi F, Bouslama A, Omezzine A, El Feki A. Impairment of spermatogenesis in rats by mercuric chloride: Involvement of low $17 \beta$-estradiol level in induction of acute oxidative stress. Biol Trace Elem Res. 2011; 142: 598-610.

Boyer TD, Vessey D, Holcomb C, Saley N. Studies of the relationship between the catalytic activity and binding of non-substrate ligands by the glutathione Stransferase. Biochem J. 1984; 217: 179-185.

Brigelius-Flohé R. Tissue-specific functions of individual glutation peroxidases. Free Radical Bio Med. 1999; 27: 951-965.

Brigelius-Flohé R. Vitamin E: The shrew waiting to be tamed. Free Radical Biol Med. 2009; 46: 543-554.

Deepmala J, Deepak M, Srivastav S, Sangeeta S, Kumar SA, Kumar SS. Protective effect of combined therapy with dithiothreitol, zinc and selenium protects acute mercury induced oxidative injury in rats. $J$ Trace Elem Med Biol. 2013; 27: 249-256.

Diplock AT, Watkins WJ, Heurson M. Selenium and heavy metals. Ann Clin Res. 1986; 18: 55-60.

Durak D, Kalender S, Uzun FG, Demir F, Kalender Y. Mercury chloride induced oxidative stres and the protective effect of vitamins $\mathrm{C}$ and $\mathrm{E}$ in human erythrocytes in vitro. Afr J Biotechnol. 2010; 9: 488495.

El-Demerdash FM. Antioxidant effect of vitamin E and selenium on lipid peroxidation, enzyme activities and biochemical parameters in rats exposed to aluminium. J Trace Elem Med Biol. 2004; 18: 113-121. 
El-Demerdash FM, Yousef MI, Kedwany FS, Baghdadi HH. Cadmium-induced changes in lipit peroxidation, blood hematology, biochemical parameters and semen quality of male rats: protective role of vitamin E and $\beta$-carotene. Food Chem Toxicol. 2004; 42: 1563-1571.

Gupta S, Gupta HK, Soni J. Effect of vitamin E and selenium supplementation on concentrations of plasma cortisol and erythrocyte lipid peroxides and the incidence of retinal fetal membranes in crossbred dairy cattle. Theriogenology. 2005; 64: 1273-1286.

Habig WH, Pabst MJ, Jakoby WB. Glutathione-Stransferases: the first enzymatic step in mercapturic acid formation. J Biol Chem. 1974; 249: 7130-7139.

Haibo Y, Zhaofa X, Wei L, Yu D, Bin X. The protective role of procyanidins and lycopene against mercuric chloride renal damage in rats. Biomed Environ Sci. 2011; 24: 550-559.

Halliwell B. Free radicals and antioxidants-quovadis? Trends Pharmacol Sci. 2011; 32: 125-130.

Hatfield DL, Tsuji PA, Carlson BA, Gladyshev VN. Selenium and selenocysteine: roles in cancer, health, and development. Trends Biochemical Sci. 2014; 39: 112-120.

Houston MC. Role of mercury toxicity in hypertension, cardiovascular disease, and stroke. J Clin Hypertens. 2011; 13: 621-627.

Jayakumar K, Jaleel CA, Vijayarengan P. Effect of different concentrations of cobalt on pigment contents of soybean. Bot Res Intl. 2009; 2: 153-156.

Jureša D, Blanuša M, Kostial $K$. Simultaneous administration of sodium selenite and mercuric chloride decreases efficacy of DMSA and DMPS in mercury elimination in rats. Toxicol Lett. 2005; 155: 97-102.

Kalender S, Uzun FG, Demir F, Uzunhisarcikli M, Aslanturk A. Mercuric chloride-induced testicular toxicity in rats and the protective role of sodium selenite and vitamin E. Food Chem Toxicol. 2013; 55: 456-462.

Kaneko JJ. Clinical biochemistry of domestic animals. 4th ed. San Diego: Academic Press; 1989.

Koyuturk M, Yanardag R, Bolkent S, Tunal S. The potential role of combined antioxidants against cadmium toxicity on liver of rats. Toxicol Ind Health. 2007; 23: 393-401.

Kumar S, Gupta S. Thymosin beta 4 prevents oxidative stress by targeting antioxidant and anti-apoptotic genes in cardiac fibroblasts. Plos One. 2011; 6: 1-13.

Lowry OH, Rosebrough NJ, Farr AL, Randall RJ. Protein measurement with the Folin phenol reagent. $J$ Biol Chem. 1951; 19: 265.

Machlin LJ. Vitamin E. In "Handbook of Vitamins," (L.J. Machlin, ed.), 2nd ed. Marcel Dekker, Inc., New York; 1991.
Mahboob M, Shireen KF, Atkinson A, Khan AT. Lipid peroxidation and antioxidant enzyme activity in different organs of mice exposed to low level of mercury. J Environ Sci Health B. 2001; 36: 687-697.

Mansour SA, Mossa ATH. Lipid peroxidation and oxidative stress in rat erythrocytes induced by chlorpyrifos and the protective effect of zinc. Pestic Biochem Phys. 2009; 93: 34-39.

Marklund S, Marklund G. Involvement of the superoxide anion radical in the autoxidation of pyrogallol and a convenient assay for superoxide dismutase. EJB. 1974; 47: 469-474.

Morakinyo AO, Iranloye, BO, Oludare GO, Oyedele OJ, Ayeni OO. Mercury chloride-induced glucose intolerance in rats: Role of oxidative stress. $\mathrm{Br} J$ Pharmacol Toxicol. 2012; 3: 7-12.

Ohkawa H, Ohishi N, Yagi K. Assay of lipid peroxidation in animal tissues by thiobarbituric acid reaction. Anal Biochem. 1979; 95: 351-358.

Oliveira CS, Oliveira VA, Ineu RP, Moraes-Silva L, Pereira ME. Biochemical parameters of pregnant rats and their offspring exposed to different doses of inorganic mercury in drinking water. Food Chem Toxicol. 2012; 50: 2382-2387.

Paglia DE, Valentine WN. Studies on the quantitative and qualitative characterization of erythrocytes glutathione peroxidase. J Lab Clin Med. 1967; 70: 158-165.

Patrick L. Mercury toxicity and antioxidants: Part I: Role of glutathione and alpha-lipoic acid in the treatment of mercury toxicity. Altern Med Rev. 2002; 7: 456-471.

Perottoni J, Rodrigues OED, Paixão MW, Zeni G, Lobato LP, Braga AL, Rocha JBT, Emanuelli T. Renal and hepatic ALA-D activity and selected oxidative stress parameters of rats exposed to inorganic mercury and organoselenium compounds. Food Chem Toxicol. 2004; 42: 17-28.

Prince PSM, Rajakumar S, Dhanasekar K. Protective effects of vanillic acid on electrocardiogram, lipid peroxidation, antioxidants, proinflammatory markers and histopathology in isoproterenol induced cardiotoxic rats. Eur J Pharmacol. 2011; 668: 233240.

Priscilla DH, Prince PSM. Cardioprotective effect of gallic acid on cardiac troponin-T, cardiac marker enzymes, lipid peroxidation products and antioxidants in experimentally induced myocardial infarction in Wistar rats. Chem Biol Interact. 2009; 179: 118-124.

Priya DKD, Gayathri R, Gunassekaran GR, Sakthisekaran D. Protective role of sulforaphane against oxidative stress mediated mitochondrial dysfunction induced by benzo (a) pyrene in female Swiss albino mice. Pulm Pharmacol Ther. 2011; 24: 110-117. 
Ramalingam V, Vimaladevi V. Effect of mercuric chloride on membrane-bound enzymes in rat testis. Asian J Androl. 2002; 4: 309-311.

Rana SVS, Rekha S, Seema V. Protective effects of few antioxidants on liver function in rats treated with cadmium and mercury. Ind J Exp Biol. 1996; 34: 177179.

Said RS, Badr AM, Nada AS, El-Demerdash E. Sodium selenite treatment restores long-lasting ovarian damageinduced by irradiation in rats: Impact on oxidative stressand apoptosis. Reprod Toxicol. 2014; 43: 85-93.

Sanz N, Diez-Fernandez C, Andres D, Cascales M. Hepatotoxicity and aging: endogenous antioxidant systems in hepatocytes from 2-, 6-, 12-, 18- and 30month-old rats following a necrogenic dose of thioacetamide. Biochim Biophys Acta. 2002; 1587: 12-20.

Schwenke DC, Behr SR. Vitamin E combined with selenium inhibits atherosclerosis in hypercholesterolemic rabbits independently of effects on plasma cholesterol concentrations. Circ Res. 1998; 83: 366-377.

Soudani N, Troudi A, Bouaziz H, Amara IB, Boudawara T, Zeghal N. Cardioprotective effects of selenium on chromium(VI)-induced toxicity in female rats. Ecotoxicol Environ Safe. 2011; 74: 513520.

Souza de Assis GP, Silva CEC, Stefanon I, Vassallo DV. Effects of small concentrations of mercury on the contractile activityof the rat ventricular myocardium. Comp Biochem Physiol. 2003; 134: 375-383.

Stajn A, Ziki RV, Ognjanovic B, Pavlovic SZ, Kostic MM, Petrovic VM. Effect of cadmium and selenium on the antioxidant defence system in rat kidneys. Comp Biochem Physiol. 1997; 2: 167-172.
Stohs SJ, Bagchi D. Oxidative mechanisms in the toxicity of metal ions. Free Radic Biol Med. 1995; 18: 321-336.

Su L, Wabg M, Yin ST, Wang HL, Chen L, Sun LG, Ruan DY. The interaction of selenium and mercury in the accumulations and oxidative stress of rat tissues. Ecotoxicol Environ Safe. 2008; 70: 483-489.

Tsuji N, Hirayanagi N, Okada M, Miyasaka H, Hirata $\mathrm{K}$, Zenk $\mathrm{MH}$, et al. Enhancement of tolerance to heavy metals and oxidative stress in Dunaliella tertiolecta by $\mathrm{Zn}$-induced phytochelatin synthesis. Biochem Bioph Res Co. 2002; 293: 653-659.

Tunali-Akbay T, Sener G, Salvarli H, Sehirli O, Yarat A. Protective effects of Ginkgo biloba extract against mercury(II)-induced cardiovascular oxidative damage in rats. Phytother Res. 2007; 21: 26-31.

Uzun FG, Demir F, Kalender S, Bas H, Kalender Y. Protective effect of catechin and quercetin on chlorpyrifos-induced lung toxicity in male rats. Food Chem Toxicol. 2010; 48: 1714-1720.

Wang Q, Ning X, Zhang Q, Liu F, Wu H, Zhang Y, et al. Molecular characterization of two glutathione peroxidase genes in Mytilus galloprovincialis and their transcriptional responses to sub-chronic arsenate and cadmium exposure. ISJ. 2014; 11: 149-62.

Yoshizawa K, Rimm EB, Morris JS, Spate VL, Hsieh CC, Spiegelman D, et al. Mercury and the risk of coronary heart disease in men. $N$ Engl J Med. 2002; 347: 1755-1760.

Zhang J, Lu S, Wang H, Zheng Q. Protective role of Aralia elata polysaccharide on mercury(II)-induced cardiovascular oxidative injury in rats. Int $J$ Biol Macromol. 2013; 59: 301-304. 